\title{
ARVOKESKUSTELU MUOTI-ILMIÖ VAI OSA SYKLIÄ?
}

\section{Syklisyys}

Henkilökohtaisesti

lukeudun niihin, jotka näkevät maailman ja sen erilaiset ilmiöt sykleinä. Niinpä on luonnollista, että arvot ja niiden muutokset ovat osa syklistä kehitystämme.

Lama ja Euroopan yhdentymiskeskustelut antavat hyvät lähtökohdat filosofeille, poliitikoille ja mielipiteenmuokkaajille nostaa esille arvokeskustelun, koska muutos tai sopeuttaminen tarvitsevat tällaista. Arvokeskustelu ja arvomaailman selittäminen on mielestäni osa muutosta.

Euroopan historia osoittaa selkeästi, että arvojen syklisyys näkyy $\mathrm{mm}$. hallinnon tai talouselämän keskittämisessä ja hajauttamisessa. Itä-Euroopan keskittävästä syklistä on siirrytty hajauttamiseen. LänsiEuroopassa on meneillään päinvastainen vaihe. Seminaarissa alustanut OTL Peter Ekholm EVA:sta puolestaan näki, että Suomessa ovat vuorotelleet 1900-luvulla yksilölliset ja kollektiiviset arvot. "Yhteisölliset arvot ovat olleet muodissa esimerkiksi 1940- ja 1970-luvuilla, yksilölliset 1920-, 50- ja 80-luvuilla. Yhteisöllisten arvojen on arvioitu nostavat päätään ja Suomi siirtyisi 90-luvun puolen välin jälkeen yhteisöllistä painottavaan suuntaan. Taloudellinen lama voi edistää muutosta."

"'On hämmästyttävää, että kun arvot muuttuvat, ajatellaan niiden joko muuttuvan huonompaan tai katoavan kokonaan. Tätä vinoutunutta suhtautumista pahentaa puhe postmodernista, suurten kertomusten kuolemisesta, keskustelu historian loppumisesta jne. Meneillään ei ole ensimmäinen eikä viimeinen mullistava vaihe ihmiskunnan historiassa."
Itse uskon Ekholmin esittämään sykliseen kehitykseen. Nythän korostetaan Euroopan yhteisön suurta merkitystä suhteessa Yhdysvaltoihin ja Japaniin, seuraavaksi meille "lanseerataan" globaalinen ajattelu. Se tapahtuu todellisesti vasta seuraavien sukupolvien aikana, kun siirrytään tietoteknologian kehittymisen myötä konkreettisiin keskusteluihin avaruuden käytöstä.

Syklisyys näkyy kaikilla elämän aloilla. Vapaa sivistystyö ei tässä suhteessa tee mitenkään poikkeusta.

\section{Arvojen tasot}

Arvojen tasolla tarkoitan yksinkertaisesti inhimillistä tarkastelunäkökulmaa. En mitään sen tieteellisempää. Yksilölliset käsitykset yhteiskunnan luomista arvoista ovat pääosin samansuuntaiset johtuen $\mathrm{mm}$. demokraattisesta hallintotavastamme. Siitä huolimatta jää aina tilaa omille yksilöllisille näkemyksille, joko julkisesti tai salaisesti, riippuen yhteiskunnan sallivuudesta.

Yhteiskunnan arvomaailma ja arvot tulevat esille päättäjien teoissa ja puheissa. Lait ja erilaiset säädökset perusteluineen ovat niiden kirjallisia ilmentymiä. Yksilö ei välttämättä miellä kaikkea oikeaksi ja hänellä jää sen hyväksymiseen tai epäilemiseen/hylkäämiseen jopa mahdollisuutensa. Yksilö voi luoda oman arvomaailmansa omilla kriteereillään. Vastaavasti perhe, ystäväpiiri jne. voivat luoda 
oman arvomaailmansa. Arvojen pysyvyys on kiinni paljolti kontakteista toisiin ihmisiin.

Pääsääntöisesti on kai nïn, että ihmisten arvot ovat dynaamisia. Tällainen ihminen kulkee ajan trendien mukaisesti. Vastavirtaan kulkijan tie on huomattavasti kivikkoisempi. Sama koskee henkilöä, joka kulkee arvoineen ja ajatuksineen muita edellä.

Alueellisesti ja paikallisesti arvot ja arvomaailma vaihtelevat. Se mikä yhtäältä on hyväksyttävää ja arvostettua, ei olekaan sitä toisaalla. Erot voivat olla suuria. Tällaisesta ristiriidasta on seurauksena sopeutumisvaikeuksia.

\section{Kuka luo arvomaailman?}

Poliittiset päätökset, poliittinen valta-asema, valtarakennelmat ja talous vaikuttavat ratkaisevasti arvomaailmoihin ja arvoihin. Arvomaailmaa muokataan ja luodaan ilmiöiden, ideologioiden ja instituutioiden kautta. Toki yksityiset henkilöt ovat joissakin tapauksissa nähtävissä esimerkiksi ideologioiden takana, mutta hekään eivät yksin ole niiden luojia.

Pohjoismainen arvomaailma ja arvot ovat varsin homogeenisia. Suomea ja Ruotsia ovat ohjanneet varsin samanlainen hyvinvointi-ideologia. Ruotsalaisten mielestä kyse on sosiaalidemokraattien luomasta kansankotiajattelusta, jolla on ollut laaja yhteiskunnallinen tuki. Suomessa samaan päämäärään on pyritty myös laajalla rintamalla.

Nyt pohjoismainen arvomaailma omaksuu entistä voimakkaammin kovia kapitalistisia periaatteita. Niinpä keskustelu arvoista ja niiden oikeutuksesta on alkanut vilkkaana. Hyvinvoinnin uhraaminen Euroopan yhteisön alttarille, kuten joku on sanonut, nostattaa keskustelunlaineita yhä korkeammalle. Arvot halutaan luoda itse ja omasta ympäristöstä, vaikka aina väitetään, että vieraat ainekset rikastuttavatkin. Nyt kuitenkin luodaan uusia arvoja myös suomalaisille.

Samanaikaisesti on mielenkiintoista, että johtamiskoulutuksessa nousee meillä keskusteluun arvoja kulttuurijohtaminen. Millä arvomaailmalla ja millä kulttuuripohjalla?

\section{Opistojen arvomaailma koetukselle}

Suomen vapaan sivistystyön laitoksissa, $\mathrm{mm}$. kansalais- ja työväenopistoissa ja kansanopistoissa on arvomaailma ollut varsin pitkälle sama kuin Ruotsin kansankoti-ideologiassa: tasa-arvo, oikeudenmukaisuus, yhteiskunnan demokraattisuuden tukeminen, työ. Nämä ajatukset löytyvät Suomen aikuiskoulutuksen kehittämispyrkimyksistä, laeista ja erilaista mietinnöistä 1960-luvulta lähtien.

Ruotsalainen yhteiskunta on romuttamassa kansankotiaan taloudellisin perustein. Näin on käymässä ilmiselvästi myös Suomessa. Ehkäpä jopa nopeammin, sillä meillä ei kansankoti koskaan edes valmistunut Ruotsin tasolle.

Suomen opistoissa ollaan taloudellisten syiden perusteella siirtymässä selvään talouspohjaiseen ajatteluun. Aikaisemman kansansivistysajatuksen tilalle nousevat kansan kohtuullisen rahastamisen mahdollisuuksien luominen. Maksupalveluperiaate, kurssimaksujen suuret korotukset ja kustannusvastuu ovat nykypäivän arvomaailman sanoja.

Missä on opistojen yhteiskunnallinen tehtävä tänään? Mitä tarkoittavat tulevan lain sanat "'ei ylläpidetä taloudellisen voiton tavoittelemiseksi'"...?

Lainlaatija ja päätöksentekijä ovat sanoneet käsityksensä arvomaailmastaan. Ei ehkä niin sitovasti kuin ennen, mutta taloudellisesti sitäkin sitovammin. Kuntien valtionosuusuudistus vuoden 1993 alusta tuo tullessaan uuden arvomaailman mukaisen vapauden. Kunnat osoittavat tästä lähtien entistä selvemmin arvomaailmansa myös opistojen työtä kohtaan. Onko kuntien arvot toiset kuin valtiolla? Onko kuntalaisten arvot muuttuneet opistoja kohtaan uuden arvomaailman myötä? Onko opistojen opiskelijoiden arvot muuttuneet siihen suuntaan, että opistot joutavat romukoppaan? Vai riittääkö se, että opistoja aletaan johtaa ajan hengen mukaisesti "'kapitalistisesti"'?

Millaiset arvot ohjaavat nykyistä 25-35 -vuotiasta naista ja miestä? Millainen on hänen arvomaailmansa? Pitääkö siihen vastata räätälöidyin opetuspalveluin? Mielestäni itsekkyys, materialismi, eriarvoisuuden korostus, taloudellisuuden ylikorostuminen eli ns. kovien arvojen nousu romuttavat opistojen toiminta-ajatusta varsin voimakkaasti. Kestävätkö opistot tässä paineessa? Vai onko tämän syklin tehtävä muokata opistot osaksi uutta arvomaailmaa? Voivatko opistot kulkea vastavirtaan?

Vastauksia saadaan seuraavan $10-15$ vuoden aikana. 